\title{
Isolation of bacteriophage-resistant Pseudomonas tolaasii strains and their pathogenic characters
}

\author{
Soo-Jin Park ${ }^{1} \cdot$ Ji-Hye Han ${ }^{1}$. Young-Kee Kim ${ }^{1}$ iD \\ 박테리오파지 저항성을 갖는 Pseudomonas tolaasii 변이주 분리 및 \\ 이들의 병원특성
}

박수진 ${ }^{1}$ • 한지혜 ${ }^{1}$ - 김영기 ${ }^{1}$

Received: 3 September 2016 / Accepted: 5 September 2016 / Published Online: 31 December 2016

(C) The Korean Society for Applied Biological Chemistry 2016

\begin{abstract}
Bacterial blotch caused by Pseudomonas tolaasii is one of the major diseases of oyster mushroom, Pleurotus ostreatus. Application of bacteriophages is a very useful tool to decrease the density of pathogens and it has been successful to making diseasefree cultivation area, known as phage therapy. Effect of phages on pathogen sterilization is very limited to the specific host strains. Minor variations of the host strains may cause changes in phage sensitivity. The phage-resistant strains of $P$. tolaasii were isolated and their pathogenic characters were investigated to improve the effectiveness of phage therapy. In the phylogenetic analysis, both phage-resistant strains and the corresponding host strains were identical based on the sequence comparison of 16S rRNA genes. The pathogenic characters, such as hemolytic activity and brown blotch formation, were measured on the phage-resistant strains and no correlation between phage-resistance and pathogenic characters was observed. Nevertheless, pathogenic characters were sometimes changed in the phage-resistant strains depending on the host strains. In order to make the phage therapy successful, the bacteriophages having a wide host range should be isolated.
\end{abstract}

Young-Kee Kim $(\triangle)$

E-mail:ykkim10@cbnu.ac.kr

${ }^{1}$ Department of Environmental and Biological Chemistry, Chungbuk National University, 1 Chungdae-ro, Cheongju, Chungbuk, Republic of Korea

This is an Open Access article distributed under the terms of the Creative Commons Attribution Non-Commercial License (http://creativecommons. org/licenses/by-nc/3.0/) which permits unrestricted non-commercial use, distribution, and reproduction in any medium, provided the original work is properly cited.
Keywords Bacteriophage $\cdot$ Brown blotch disease $\cdot$ Phage-resistant bacteria $\cdot$ Phylogenetic analysis $\cdot$ Pseudomonas tolaasii

\section{서 론}

느타리버섯은 국내 버섯산업에서 생산량과 소비량 모두에서 상 위권을 차지하고 있으며, 재배에 따른 고소득이 가능하여 농가 에서 선호도가 높은 작물이다. 그럼에도 불구하고 세균성갈반병 (Iacobellis와 Lo Cantore 1998)의 빈번한 발생은 느타리버섯의 재배를 어렵게 하고 있다. 느타리버섯의 갈반병을 예방하기 위 하여 농용 지하수를 철저히 살균하거나, 재배사를 훈증소독하고, 비닐멀칭이나 봉지, 병을 이용한 재배 방법(Geels 등, 1991) 등 이 다양하게 개발되어 왔음에도 현재까지 효과적인 예방이나 방 제방법은 개발되지 못하였고, 발병시에 대책은 없는 실정이다. 박테리오파지(bacteriophage)는 바이러스의 한 종류로서, 최근 다 양한 항생제에 내성을 가진 세균의 출현에 따라 기존 항생제의 대체방안으로 연구의 중심이 되고 있다(Housby와 Mann 2009; $\mathrm{Lu}$ 와 Koeris 2011). 항생제의 과다사용과 항생제 저항성 유전자 의 전이, 세균의 진화에 따른 항생제 내성균의 생성과 항생제 저항성의 증가는 새로운 항균물질을 필요로 하고 있고, 박테리 오파지나 항세균성 펩티드, 단백질, 나노입자 등이 개발되고 있 다. 이들 중 박테리오파지는 기본적으로 자체 독성이 없기에 2000년 이후 미국 및 유럽의 산업체에서 제품화되어 이용되고 있으나(Abedon과 Thomas-Abedon 2010), 파지의 생태학적, 생 물학적 이해가 부족하여 파지테라피에 대한 부정적 견해와 사 용상의 약점도 커져왔다(Skurnik와 Strauch 2006). 파지에 대한 꾸준한 연구로 파지의 생태가 밝혀지고 있고, 숙주균 범위의 제 
한성, 제품화, 임상적 처리방법 등의 발전에 따라 파지관련 생 산품들이 FDA, USDA, EPA 등에서 사용허가를 받았고(FDA 2006), 대장균이나 살모넬라 균 등 병원성 세균을 방제하기 위 한 파지관련 생산물들이 개발되고 있다(Abuladze 등, 2008).

본 연구에서는 갈반병이 발생한 느타리버섯 재배농가에서 병 원성 균주들을 분리동정하여 분류하였고(Yun 등, 2013; Mu 등, 2015), 이들을 억제하는 독성파지를 재배사 인근이나 농가 인근 의 하수에서 분리하였다. 분리한 파지는 파지테라피에 사용하기 위하여 숙주균에 대한 민감도를 조사하였고, 숙주균의 사멸효과 가 높은 파지혼합액을 구성할 파지 종류를 선정하였다. 파지는 갈반병 균주에 매우 특이적으로 작용하였고 살균효과가 뛰어나 파지테라피를 위한 유용한 균주로 확인되었다. 하지만, 파지와 숙주균의 배양시간이 길어짐에 따라 파지에 대하여 저항성을 갖 는 균주가 나타났기에, 원래의 숙주균과 여기서 발생한 파지저 항성 균주들의 특성조사를 위하여 유전자적, 생화학적, 병원성 의 차이를 조사하였다.

\section{재료 및 방법}

\section{파지저항성 균주의 분리}

파지저항성 균주는 갈반병 원인균주 Pseudomonas tolaasii를 Pseudomonas agar F (Bacto-peptone $10 \mathrm{~g}$, Bacto-tryptone $10 \mathrm{~g}$, $\mathrm{K}_{2} \mathrm{HPO}_{4} 1.5 \mathrm{~g}, \mathrm{MgSO}_{4} 1.5 \mathrm{~g}$, glycerol $10 \mathrm{~mL}$, agar $15 \mathrm{~g} / \mathrm{L}$ ) 평 판배지 위에 도말한 뒤 파지를 점적하여 $25^{\circ} \mathrm{C}$ 에서 48 시간 동 안 배양하며, 용균반 내부에서 발생한 콜로니에서 분리하였다.

\section{생화학적 대사 측정}

분리한 저항성균주의 특성을 조사하기 위하여 API kit (Biomérieux, Paris, France)를 이용하여 생화학적 대사특성을 측 정하였다. 측정방법은 제조사의 지침을 따랐으며, 간략히 저항 성 균주의 콜로니를 분리하여 현탁하고, $\mathrm{NO}_{3}$ 부터 $\mathrm{PNPG}$ 까지 8 개의 큐플의 아랫부분에 주입하였다. 이 중 $\mathrm{GLU}, \mathrm{ADH}, \mathrm{URE}$ 는 무기오일을 첨가하여 혐기성 조건으로 만들어줬다. 나머지 측정의 경우는 균주 균질액을 큐플의 윗부분까지 채워준 후 키 트를 $29 \pm 2{ }^{\circ} \mathrm{C}$ 에서 24 시간동안 배양하고 지침에 따라 결과를 판 정하였다.

\section{버섯조직함몰 검정법}

버섯조직 함몰검정(pitting test)은 Gandy (1968)의 방법에 따라 양송이버섯을 이용하여 실시하였다. 양송이버섯은 갓 부분을 절 단하여 사용하였다. 버섯의 갓 위 부분 $1 / 3$ 을 절단하고, 절단면 에 균주의 배양액 $\left(10^{8}-10^{9} \mathrm{cfu} / \mathrm{mL}\right)$ 이나 tolaasin 추출액 $10 \mu \mathrm{L}$ 점적하여 흡수시켰다. 이것을 증류수로 적신 여과지를 깔아준 사각플라스틱 용기(square dish)에 담아 12-24시간 동안 항온기 에서 $25^{\circ} \mathrm{C}$ 로 배양하였다. 버섯을 넣은 후에는 밀봉하여 수분 증발을 방지하였다. 최종적인 평가는 점적부위의 변색과 함몰을 관찰하여 이루어졌다.
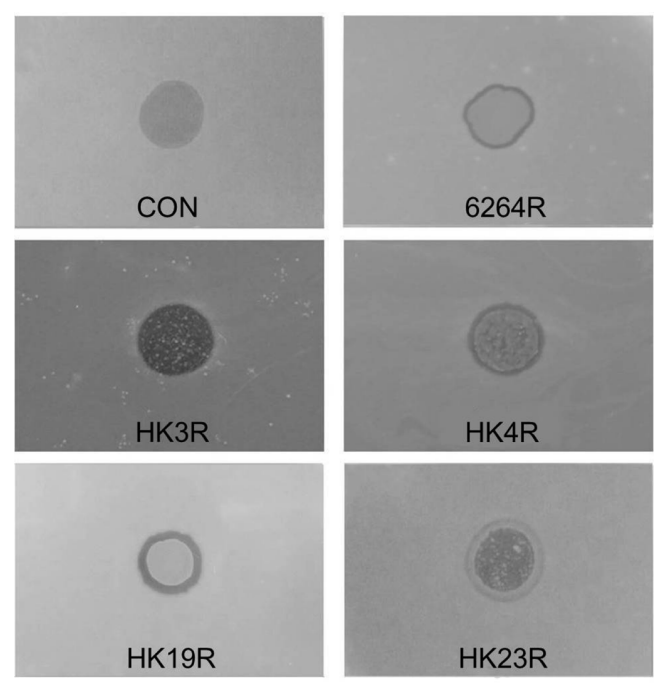

Fig. 1 Colony formations of phage-resistant bacteria inside the plaques. Con: plaque without resistant strains. R-strains are phage-resistant strains of the corresponding strains

\section{결 과}

\section{파지저항성 균주의 분리}

본 연구에서는 느타리버섯 재배 시 큰 피해를 유발하는 세균성 갈반병의 방제를 위하여, 사용이 금지된 농약이나 항생제 대신 에 숙주균에 특이적이며 사멸효과가 큰 박테리오파지를 이용하 여 친환경적인 파지테라피 방법을 개발하고자 하였다. 갈반병 등을 유발한 균주들을 재배농가에서 분리하여 $16 \mathrm{~S} \mathrm{rRNA}$ 유전 자 분석을 통하여 동정하였고, 이들 중 병원균인 Pseudomonas tolaasii에 속하는 균주 총 23 종을 동정하였으며, 이들을 $\mathrm{P} 1$ 그룹 으로 명명하였다. 또한, 이들을 다시 phylogenetic tree 분석을 통하여 크게 3종류로 분류하여 $\mathrm{P} 1 \alpha, \mathrm{P} 1 \beta, \mathrm{P} 1 \gamma$ 로 명명하였다 (Yun 등, 2013). 갈반병이 발생한 농가에서 수집한 병원성 균주 를 숙주균으로 이용하여 특이적인 박테리오파지를 분리하였고, 파지의 숙주균 사멸활성은 숙주균의 배지에 파지를 감염시켰을 때, 파지의 감염으로 숙주균이 사멸되어 나타나는 투명한 용균 반(plaque)의 형성으로 확인하였다. 파지의 숙주균에 대한 독성 에 따라 12 시간 이상 배양하였을 때, 파지에 의한 용균반 형성 과 용균반의 크기나 투명도가 다르게 나타났다(Kim 등, 2011).

병원성 숙주균에 대한 파지의 독성실험 중 2 일 이상 배양하 는 경우 시간의 경과에 따라서 투명했던 용균반 내부에 자주 세균의 성장이 관측되었으며, 새로이 나타난 세균은 용균반을 만든 파지에 감염되지 않거나 파지의 감염에 둔감한 파지-저항 성 균주인 것으로 확인하였다. 용균반 관측실험은 숙주균과 파 지를 제외하고 무균 조건에서 수행되었기에 새로이 용균반 내 에서 나타난 균주는 원래의 숙주균이 파지에 대하여 저항성을 획득함으로써 나타난 것으로 추정하고, 이 균주들을 분리하여 특성을 조사하였다. 균주의 분리는 고체배지의 상부에 반고체배 
지를 만들고 파지를 접종하여 용균반을 생성시킨 후, 용균반 내 부에서 성장하는 세균의 콜로니를 분리하여 얻었다(Fig. 1).

파지저항성 균주는 용균반 내부에 불투명한 균주성장반을 형 성하거나, 다수의 콜로니 형태로 나타났다. 먼저, P. tolaasii 균 주 중 P1 $\alpha$ 세분류에 속하는 숙주균인 P. tolaasii 6264와 HK2, $\mathrm{HK} 3, \mathrm{HK} 4, \mathrm{HK} 5$ 에 각각의 특이적 파지인 $\phi 6264, \phi \mathrm{HK} 2$, $\phi \mathrm{HK} 3, \phi \mathrm{HK} 4, \phi \mathrm{HK} 5$ 를 접종하였고, 다른 세분류 $\mathrm{P} 1 \beta, \mathrm{P} 1 \gamma$ 에 속하는 숙주균 P. tolaasii HK19, P. tolaasii HK23에 각각 $\phi \mathrm{HK} 19$ 와 $\phi \mathrm{HK} 23$ 를 접종하였다. 시간이 경과함에 따라 용균반 내부에서 저항성 균주의 콜로니가 발생하는 것을 확인하였다 (Fig. 1). 파지 저항성을 획득한 P. tolaasii 6264 균주는 원래의 숙주균과 구별하기 위하여 P. tolaasii 6264R로 명명하였으며, 마찬가지로 파지저항성을 획득한 P. tolaasii $\mathrm{HK} 2$ 는 P. tolaasii $\mathrm{HK} 2 \mathrm{R}$ 로 나타내, 파지 저항성 균주의 변종번호에 $\mathrm{R}$ 을 가하여 변종을 구별하였다.

파지저항성 균주들의 콜로니 양태를 관측하면 P. tolaasii 6264R 균주와 HK19R 균주는 용균반 전체로 퍼져 나타났으며, 저항성균 성장반 주위에는 파지의 확산에 따라 용균반 밖에는 파지감수성 균이, 내부에는 파지저항성 균이 성장하여 퍼지는 상태로 이 사이에는 투명한 용균선이 관측되었다. 그러나, 같은 $\mathrm{P} 1 \alpha$ 세분류 균주의 파지 감염에서 얻어진 $\mathrm{HK} 2 \mathrm{R}$ 균주와 $\mathrm{HK} 3 \mathrm{R}, \mathrm{HK} 4 \mathrm{R}, \mathrm{HK} 5 \mathrm{R}$ 균주들은 저항성균주 성장반을 형성하지 않고 용균반 내부에 다수의 콜로니를 형성하였고, $\mathrm{P} 1 \gamma$ 세분류 균주의 파지 감염에서 얻어진 $\mathrm{HK} 23 \mathrm{R}$ 은 저항성균주 성장반과 콜로니 형태 두 가지 모두 관측되었다.

\section{균주의 유전적 특성}

저항성 균주가 원래의 숙주균으로부터 유래된 것을 확인하기 위 하여 $16 \mathrm{~S} \mathrm{rRNA}$ 유전자 염기서열을 분석하고, 원래의 숙주균의 염기서열과 비교하였다. 각각의 숙주균으로부터 얻은 저항성균 의 유전자 염기서열은 정확하게 숙주균의 유전자와 일치하였으 며, 계통수 분석에서 같은 균주로 확인되었다(Fig. 2). 이러한 결과는 각 저항성 균주가 원래의 숙주균으로부터 유래하였음을 보여주며, 파지에 대한 저항성을 획득하는 과정에서 $16 \mathrm{~S} \mathrm{rRNA}$ 유전자의 염기서열에는 전혀 변화가 없었음을 확인하였다.

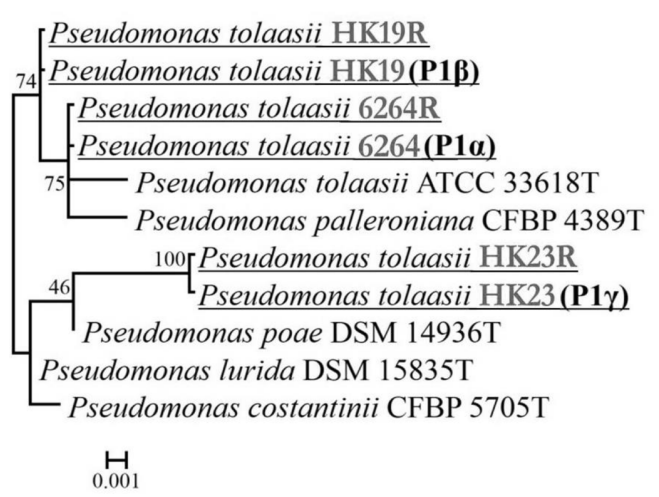

Fig. 2 Phylogenetic analysis of phage-resistant strains compared to the original host strains

\section{균주의 생화학적 특성}

파지저항성 획득으로 인한 균주의 대사특성에 변화 여부를 확 인하기 위하여 API kit를 이용하였고, 총 22가지의 대사활성을 원래의 숙주균과 비교하여 측정하였다. $\mathrm{P} 1 \alpha$ 세분류 균주들의 생화학적 활성은 Table 1에 보였다. 숙주균과 저항성 변이주 사 이에 대부분의 생화학적 대사활성이 일치하였으나, P. tolaasii $6264 \mathrm{R}$ 과 HK2R 균주의 경우 각각 7 가지와 8 가지의 대사활성 이 원래의 숙주균과 차이를 보여 파지저항성 획득과 함께 생화 학적 대사활성에도 큰 변화가 나타났다. 그러나, HK3R 균주와 $\mathrm{HK} 4 \mathrm{R}$ 균주, HK5R 균주는 각각 1가지, 3 가지, 1 가지의 대사활 성이 원래의 숙주균과 다르게 나타나, 파지저항성 변이주의 생 화학적 활성은 원래의 숙주균과 큰 변화를 보이지 않았다. P1 $\beta$ 와 $\mathrm{P} 1 \gamma$ 세분류 균주는 각각 P. tolaasii $\mathrm{HK} 19 \mathrm{R}$ 균주와 HK23R 을 대표균주로 생화학적 대사 변화여부를 조사하였으나, HK19R 저항성 균주의 경우 대사활성의 변화가 없었고, HK23R 균주는 1 가지 대사활성의 변화가 있었다(Table 2). 이상의 결과를 통하 여 숙주균이 파지저항성을 획득할 때, 파지저항성 획득과 동시 에 대사활성에도 변화가 유발될 수 있으나 변화정도는 균주에 따라 다르게 나타남을 알 수 있었다.

Table 1 Comparison of metabolic activities between $\mathrm{P} 1 \alpha$ strains and their corresponding phage-resistant strains

\begin{tabular}{lccccccccccccccccc}
\hline \multicolumn{2}{c}{ Test } & $\mathrm{NO}_{3}$ & TRP & GLU & ADH & ESC & GEL & PNPG & GLU & MNE & MAN & NAG & MAL & GNT & CAP & MLT & CIT \\
\hline 6264 & - & - & - & + & - & - & - & + & + & - & + & - & - & + & + & + \\
$6264 R$ & + & - & + & - & + & - & + & + & + & - & + & + & - & - & + & + \\
HK2 & - & - & - & - & + & + & + & + & + & - & + & + & - & - & + & + \\
HK2R & - & - & - & - & + & - & - & - & - & - & - & - & - & - & - & - \\
HK3 & - & - & - & + & - & + & - & + & + & - & + & - & - & + & + & + \\
HK3R & - & - & - & + & - & + & - & + & + & - & + & - & - & + & + & - \\
HK4 & - & - & - & + & - & + & - & + & + & - & + & - & - & + & + & + \\
HK4R & - & - & - & + & - & + & - & + & - & - & - & - & - & - & + & + \\
HK5 & - & + & - & + & + & - & - & + & + & + & + & - & + & + & + & + \\
HK5R & - & + & - & - & + & - & - & + & + & + & + & - & + & + & + & + \\
\hline
\end{tabular}

API Kit (20NE) was used to be measured the metabolic activities of all strains. The same results were obtained by all strains in the items: URE (-), ARA (-), ADI (-), PAC (-), OX (+) 


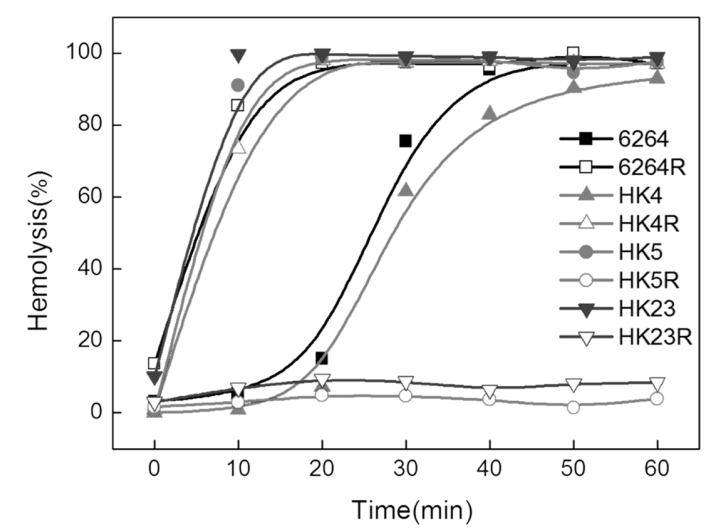

Fig. 3 Hemolytic activities of phage-resistant strains

\section{펩티드독소의 용혈활성 변화여부}

갈반병 병원균 P. tolaasi 는 tolaasin을 분비하여 세포독성을 나 타내는데, tolaasin은 느타리버섯의 세포막에 pore를 형성하여 버 섯조직을 파괴하는 펩티드독소이다. 세포독성의 측정은 본래의 숙주균과 파지저항성 균주의 세포독성과 병원성 변화여부를 확 인하기 위하여 실시하였다. 파지저항성 균주의 세포독성 측정은 쥐의 적혈구를 이용한 용혈활성 검정(hemolysis test)과 양송이 버섯을 이용한 버섯함몰 검정법(pitting test)으로 이루어졌다.

병원성균주의 용혈활성은 균주가 분비하는 펩티드 독소의 세 포독성에 의해 나타나는데, 이것은 독소와 적혈구 세포막 사이 의 결합친화도(binding affinity)와 균주의 생육에 시기에 따른 독소의 분비량에 의해서도 차이가 난다. 용혈활성의 측정은 쥐 의 적혈구를 독소와 배양하며 배양시간에 따른 세포의 파괴를 측정하여 이루어졌다(Fig. 3). P. tolaasii 6264와 HK4 배양액을 처리한 경우 모든 적혈구를 용혈시키는데에 각각 40 분, 60 분이 소요되었지만, 각각의 파지저항성 균주인 6264R과 $\mathrm{HK} 4 \mathrm{R}$ 균주 는 20 분이내에 모든 적혈구를 완전히 용혈시키는 높은 활성을 보여 파지저항성 획득과정중 세포독성이 증가한 것을 알 수 있 었다. 반면, P. tolaasii $\mathrm{HK} 5$ 와 $\mathrm{HK} 23$ 의 경우, 숙주균의 세포독 성은 매우 크게 나타났으나, 파지저항성 균주의 용혈활성은 완 전히 없어져 적혈구의 파괴는 나타나지 않았다. P. tolaasii $\mathrm{HK} 2, \mathrm{HK} 19, \mathrm{HK} 3$ 균주의 경우 파지저항성 획득에 따라 용혈 활성 변화는 관측되지 않아 변화가 없었다. 이상의 결과에서 파 지저항성 균주의 세포독성 변화는 균주마다 다른 양상을 보여, 각 균주마다 파지에 대한 저항성을 획득할 때 파지저항성과 무

Table 2 Comparison of metabolic activities between $\mathrm{P} 1 \beta$ and $\mathrm{P} 1 \gamma$ strains and their corresponding phage-resistant strains

\begin{tabular}{ccccc}
\hline Strain & Test & ADH & GEL & ARA \\
\hline HK19 & - & + & - \\
HK19R & - & + & - \\
HK23 & + & - & + \\
HK23R & - & - & + \\
\hline
\end{tabular}

The same results obtained by all strains: $\mathrm{NO}_{3}(-), \mathrm{TRP}(+)$, GLU (-), URE $(-), \operatorname{ESC}(+)$, PNPG (-), GLU (+), MNE (+), MAN (+), NAG (+), MAL $(-)$, GNT $(+)$, CAP $(+)$, ADI $(+)$, MLT $(+)$, CIT $(+)$, PAC $(-)$, OX $(+)$
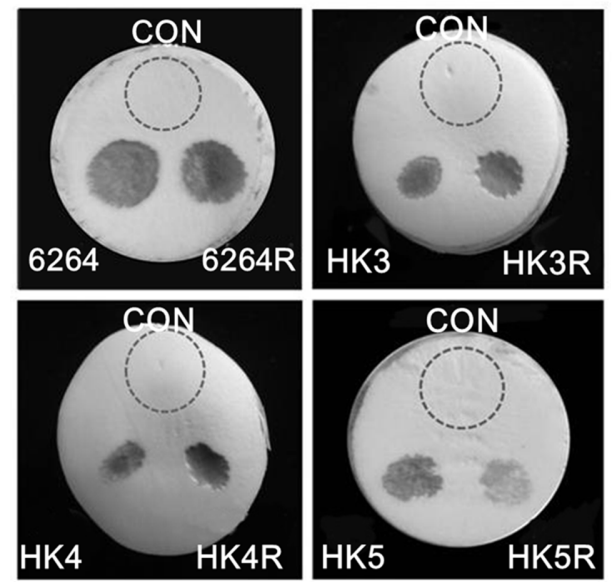

Fig. 4 Brown blotch formations by the phage-resistant strains

관하게 세포독성 등의 생리생화학적 특성에 변화가 일어났음을 확인하였다.

\section{파지저항성 균주의 갈반형성능}

파지저항성 균주의 세포독성 변화 여부를 측정하기 위하여 병 원성 균주의 갈반형성 측정법인 버섯조직함몰검정법으로 독성 변화를 확인하였다. 이 검정법은 실제 갈반병이 발생하는 버섯 조직에 균주의 독소를 처리하여 병원성을 측정하는 방법으로, 버섯 조직의 파괴정도를 측정할 수 있다. Fig. 4에서 P. tolaasii 6264 균주의 경우 파지저항성 획득에 따른 갈반형성능의 변화 는 나타나지 않았다. 반면, P. tolaasii HK3와 HK4 균주는 저 항성 획득에 따라 갈반의 깊이가 깊어지고 갈색이 짙어지는 결 과로 갈반형성능이 커짐을 확인하였고, P. tolaasii $\mathrm{HK} 5$ 균주의 경우 저항성 균주에서 갈반형성이 약해져 세포독성이 작아짐을 보였다. 한편, $\mathrm{HK} 2, \mathrm{HK} 19, \mathrm{HK} 23$ 균주의 갈반생성은 저항성 획득에 따라 변화가 없었다.

버섯함몰 검정법에 따른 측정결과와 용혈활성 측정 결과를 비교하였을 때, $6264 \mathrm{R}$ 균주는 용혈활성이 증가하였지만 버섯함 몰활성은 변함이 없었고, $\mathrm{HK} 4 \mathrm{R}$ 의 경우에는 용혈활성과 버섯함 몰 활성이 모두 증가한 것으로 확인되었다. 또한 용혈활성이 사 라진 $\mathrm{HK} 5 \mathrm{R}$ 균주의 버섯함몰 활성이 원래의 P. tolaasii HK5 균주의 버섯함몰 활성보다 낮아진 것을 볼 수 있었다. 그러나, $\mathrm{HK} 23 \mathrm{R}$ 와 HK3R 균주의 경우는 용혈활성은 사라지거나 작아졌 으나 갈반형성능은 원래의 균보다 오히려 증가한 것을 볼 수 있었다. 용혈활성이 없는 P. tolaasii HK19와 HK19R 균주는 비슷한 버섯함몰활성을 가지고 있었다. 이러한 결과는 파지저항 성과 용혈활성, 갈반 형성능에 일정한 상관성이 없음을 의미한다.

\section{고 찰}

느타리버섯의 상업적 대량재배에서 가장 문제가 되는 것은 세 균성갈반병의 발생이고, 본 연구는 박테리오파지를 이용하여 친 환경적으로 갈반병 세균을 제어할 수 있는 방안을 강구하는 일 환으로 수행되었다. 세균성갈반병은 P. tolaasii 균주가 분비하는 
펩티드인 tolaasin에 의해서 버섯세포가 파괴되어 나타나는 병 징으로, 이를 분비하는 병원성세균을 박테리오파지를 이용하여 사멸시키면 근원적인 갈반병의 억제가 가능할 것이라는 파지테 라피 방법이다. 느타리버섯 재배농가에서 세균성갈반병 유발균 주인 P. tolaasii 균과 이를 제어하는 독성파지(virulent phage)를 분리하고, 효과적인 파지테라피 방안을 선행연구를 통하여 마련 하였다. 병원성 세균인 갈반병균의 특성과 파지를 이용한 파지 테라피의 효과는 입증하였으나(Yun 등, 2013), 파지의 특성이나 파지테라피의 단점인 파지저항성 균주에 관련된 연구가 추가적 으로 요구되었다. 파지는 숙주균에 매우 특이적으로 작용하여 저항성이 없는 병원성 숙주균을 효과적으로 사멸시키나, 숙주균 이 파지에 대하여 저항성을 가질 수 있기 때문에 한 숙주균에 대하여 사멸효과를 갖은 2 가지 이상의 파지를 선정하여 혼합처 리 한다면 저항성균의 피해를 효과적으로 막을 수 있을 것이다 (David 등, 2011).

파지저항성 균주는 파지민감성 균주가 파지의 세균침투 기작 을 저해하는 능력의 획득으로 나타난다(Labrie 등, 2010). 파지 저항성 능력은 숙주균이 다양한 파지흡착 기작을 저해하거나, 파지유전자의 유입을 막거나, 파지유전자를 절단하여 무력화시 키거나, 파지유전자의 작용을 억제하는 등의 능력을 갖게 됨으 로써 나타난다. 파지저항성 균주는 파지테라피 시에 종종 발생 하여 파지혼합액의 효과를 무력화시킬 수 있으므로 파지저항성 균주의 병원특성의 조사가 필요하다. 파지가 용균반을 생성하였 을 때, 일부 균주의 경우 투명한 용균반 내부에서 불투명한 균 주성장반이나 콜로니를 발견하였다. 용균반 내부에서 생장하는 균주는 숙주균에 파지를 처리하였을 때 저항성을 획득하여 나 타났거나, 아니면 파지가 특이적으로 작용하지 못하는 다른 균 주의 오염에 의해서 나타났을 것이다. 새로이 나타난 균주의 $16 \mathrm{~S}$ rRNA 유전자 염기서열을 분석하고 계통수 분석을 수행하 였을 때, 기존의 숙주균과 파지저항성 균주로 분리된 균주가 같 게 분류되어 새로이 나타난 균주는 숙주균이 파지저항성을 획 득한 것임을 확인하였다.

이렇게 얻어진 파지저항성 균주는 동일한 파지에 의해 사멸 되지 않았다. 그러므로 파지에 대한 저항성 획득 과정 중 균주 의 특성에 어떠한 변화가 있었는지 확인하기 위하여 생화학적 대사의 변화, 세포독성을 평가하는 용혈활성과 갈반형성능의 변 화를 측정하였다. 파지저항성을 획득한 균주들은 유전적인 특성 이 같은 $\mathrm{P} 1 \alpha$ 균주임에도 불구하고 각각 다른 변화가 관찰되어 생화학적 대사특성과 파지 저항성 사이에는 일정한 상관성이 없 다는 결론을 얻었다. 그러나, 이러한 파지저항성 균주 중 $\mathrm{HK} 5 \mathrm{R}$ 은 용혈활성과 버섯함몰 활성을 기존의 균주와 비교하였을 때, 세포독성이 약해지거나 사라져 적혈구 파괴가 이루어지지 않았 고, 갈반형성이 약해지는 것을 확인하였다. 이는 P. tolaasii HK5 균주가 파지 $\phi \mathrm{HK} 5$ 의 자극에 의해 저항성을 획득할 때, 세포독성 물질을 분비하지 못하는 비병원성 균주로 변이 된 것 으로 보인다(Simon 등, 2010; Julie 등, 2013). 이것은 HK23 균주에서도 유사하게 관측되어 파지저항성 획득과 세포독성 감 소 사이에 상관관계를 분자수준에서 조사하여 밝혀냄으로써 숙 주균 특성에서의 파지테라피 문제점을 이해하여야 이 방법의 효 율을 높일 수 있을 것이다.

\section{초 록}

세균성 갈반병은 느타리버섯(Pleurotus ostreatus)의 주된 병중의 하나이다. 박테리오파지를 이용한 파지테라피 방법은 병원균의 농도를 감소시켜 병없는 재배사를 만드는데 성공적이었다. 병원 균 사멸을 위한 파지의 이용은 숙주균의 특이성 때문에 매우 제한적 효과를 보이며, 이것은 병원균의 작은 변이에도 파지의 민감성은 크게 감소할 수 있기 때문이다. 본 연구에서는 파지 테라피의 효용성을 높이기 위하여 갈반병의 원인균인 P. tolaasii 균주로부터 파지-저항성 변이주를 분리하였고 병원성 특성을 조 사하였다. $16 \mathrm{~S}$ rRNA 유전자의 염기서열 분석을 통한 근연관계 분석에서 파지저항성 균주들은 모두 원래의 숙주균과 일치하였 고, 용혈활성이나 갈반형성 능력 등 병원성은 파지저항성 획득 과 관련이 없는 것으로 확인되었다. 그럼에도 불구하고, 파지저 항성 균주의 다양한 병원성은 균의 종류에 따라 증감이 다르게 나타났다. 따라서, 성공적인 파지테라피를 위해서는 넓은 숙주 범위를 갖는 파지의 분리가 필요하다.

Keywords 갈반병 · 계통분석 · 박테리오파지 · 슈도모나스 톨라 시 · 파지-저항성균

감사의 글 본 연구는 농림축산식품부 의 재원으로 농림수산식품기술기획 평가원 농생명산업기술개발사업의 연구비 지원에 의하여 이루어 졌습니다.

\section{References}

Abedon ST, Thomas-Abedon C (2010) Phage therapy pharmacology. Curr Pharm Biotechnol 11: 28-47

Abuladze T, Li M, Menetrez MY, Dean T, Senecal A, Sulakvelidze A (2008) Bacteriophages reduce experimental contamination of hard surfaces, tomato, spinach, broccoli, and ground beef by Escherichia coli $\mathrm{O} 157: \mathrm{H} 7$. Appl Environ Microbiol 74: 6230-6238

David K, Olivia MR. Paul R, Jim O, Aidan C (2011) Development of a broad-host-range phage cocktail for biocontrol. Bioeng Bugs 2: 31-37

FDA (2006) Food additives permitted for direct addition to food for human consumption; Bacteriophage preparation. Federal Register 71: 4772947732

Gandy DG (1968) A technique for screening bacteria causing brown blotch of cultivated mushrooms. Annual Report of the Glasshouse Crops Research Institute for 1967: 150-154

Geels FP, Griensven LD, Rutjens AJ (1991) Chlorine dioxide and the control of bacterial blotch on mushrooms, caused by Pseudomonas tolaasii. In: Maher MJ (ed), Science and Cultivation of Edible Fungi, Balkema Publisher, USA, pp 437-442

Housby JN, Mann NH (2009) Phage therapy. Drug Discov Today 14: 536540

Iacobellis NS, Lo Cantore P (1998) Recenti acquisizioni sul determinismo della batteriosi del cardoncello (Pleurotus eryngii). Agricoltura Ricerca 176: $51-54$

Julie ES, Alfonso HM, Mourad S, Sylvain M (2013) Revenge of the phages: defeating bacterial defences. Nat Rev Microbiol 11: 675-687

Kim MH, Park SW, Kim YK (2011) Bacteriophages of Pseudomonas tolaasii for the biological control of brown blotch disease. J Korean Soc Appl Biol Chem 54: 99-104

Labrie SJ, Samson JE, Moineau S (2010) Bacteriophage resistance 
mechanisms. Nature Rev Microbiol 8: 317-327

Lu TK, Koeris MS (2011) The next generation of bacteriophage therapy. Curr Opi Micorbiol 14: 524-531

Mu LL, Yun YB, Park SJ, Cha JS, Kim YK (2015) Various pathogenic Pseudomonas strains that cause brown blotch disease in cultivated mushroom. J Appl Biol Chem 58: 349-354

Simon JL, Julie ES, Sylvain M (2010) Bacteriophage resistance mechanisms.
Nat Rev Microbiol 8: 317-327

Skurnik M, Strauch E (2006) Phage therapy: facts and fiction. Int J Med Microbiol 296: 5-14

Yun YB, Park SW, Kim YK (2013) Biological characterization of various strains of Pseudomonas tolaasii that causes brown blotch disease. J Koreans Soc Appl Biol Chem 56: 41-45 